\title{
GERMAN REPARATIONS TO POLAND FOR WORLD WAR II ON GLOBAL BACKGROUND
}

\author{
Grzegorz KOSTRZEWA-ZORBAS
}

Military University of Technology

\begin{abstract}
No other country in the world suffered a greater measurable and verifiable loss of human and material resources than Poland during World War II in 1939-1945. According to the first approximation, the value of human and material losses inflicted to Poland by Nazi Germany amounts to 6.495 trillion US dollars of 2018. However, Poland never received war reparations from Germany. The article is a preliminary survey of the complex issue - conducted in an interdisciplinary way combining elements of legal, economic, and political analysis, because the topic belongs to the wide and multidisciplinary field of national and international security. Refuted in the article is an internationally popular myth that communist Poland unilaterally renounced German war reparations in 1953. Then the article discusses the global background of the topic in the 20th and 21st centuries - in particular, the case of Greece whose reparations claims Germany rejects like the Polish claims, and major cases of reparations actually paid: by Germany for World War I, by Germany to Israel and Jewish organizations for the Holocaust, by Japan for World War II - at 966 billion US dollars of 2018, the largest reparations ever - and by and Iraq for the Gulf War. The article concludes with a discussion of necessary further research with advanced methodology of several sciences, and of a possible litigation before the International Court of Justice - or a diplomatic solution to the problem of war reparations. Keywords: war reparations, war compensation, World War II, Poland, Germany, Third Reich, Nazi Germany, war crimes, genocide, Holocaust, Jews, Israel, Soviet Union, Japan, Greece, Iraq, Gulf War, international law, United Nations, International Court of Justice.
\end{abstract}

\section{Introduction to a multidisciplinary preview}

Since the emergence of reliable statistical data sources, and of the sciences of economics, econometrics, and demographics that allow to measure the extermination of peoples and civilizations, no other country suffered a greater measurable and verifiable loss of human and material resources than Poland during World War II. Poland fell victim to the two largest totalitarian powers ever: the Nazi Third German Reich and the Stalinist Soviet Union. After World War II, it was a torturous irony of history that communism prevented Poland from exercising the right to seek justice for the destruction perpetrated by the Nazis.

Poland was the first nation that militarily resisted Adolf Hitler. Polish land, air, and naval forces fought against Nazi Germany in all parts of Europe and on the Atlantic Ocean until the last day of the war. While establishing the post-World War II order in Europe and the world, however, the then great and dominant powers did not want Poland to participate in big international politics and in big transfers of economic resources. Poland was condemned to living in poverty and humiliation, feeling powerless and hopeless, and learning that it cannot maintain any ambitions 
to defend even those rights and interests that were obvious for large states and for many small states. By the 2010s, most of the Polish generations directly affected by World War II passed on, uncompensated for the horrible injustice until the very end of their lives.

Polish citizens rebuilt the country on their own cost, thanks to their hard work, energy, and creativity. In particular, the reconstruction of Warsaw, conducted without any German reparations, became the greatest successful reconstruction of a city in the history of the world - recognized for exactly this reason on UNESCO World Heritage List. ${ }^{1}$ Nazi Germany systematically and almost totally depopulated, plundered and ruined Warsaw, and never delivered any compensation for that genocidal crime. A major part of the annihilation of Warsaw was a nearly complete extermination of its Jews - the then second largest urban community of Jews in the world, after that of New York City. Many other Polish cities, towns, and villages experienced massive death, destruction, and plunder. If Poland as a whole had received due reparations and had added them to its own resources for reconstruction, and for economic and civilizational development, it would have achieved the high level of development of the Northwest of Europe before the end of the 20th century.

The estimated monetary equivalent of the human and material losses inflicted by Nazi Germany on Poland in World War II exceeds six trillion 2017 United States dollars. In 2014, I discovered the fact that Poland never registered with the United Nations an act of renouncement of the due reparations and, therefore, never legally waived them. My discovery, together with a comprehensive legal and political analysis of the broader question of war reparations in Europe and the world - and with recommendations for Poland's possible diplomatic and legal action to pursue claims against Germany, including litigation before the International Court of Justice in The Hague - was first published on 29 September 2014. ${ }^{2}$

Germany responded in 2014 that all claims related to World War II were finally settled in 1990 with the signing of the German reunification treaty. ${ }^{3}$ In 2015, however, Germany awarded financial compensation to surviving veterans of the Red Army of the Soviet Union who were, as prisoners of war, subject to inhumane treatment in Nazi German camps. The total amount of the compensation was only 10 million euros - of mainly symbolic value - but Germany proved that it does not actually implement its own position on the final settlement of claims. Germany made many

1 United Nations Educational, Scientific and Cultural Organization (UNESCO), World Heritage List, Historic Centre of Warsaw, https://whc.unesco.org/en/list/30 (last accessed: 3 October 2018).

2 G. Kostrzewa-Zorbas, "Biliony dolarów za II wojnę światową" ["Trillions of Dollars for World War II"], wSieci, 29 September-5 October 2014. My next media article focused mainly on other major cases of war reparations in the world: G. Kostrzewa-Zorbas, "Mamy prawo do odszkodowań" ["We Have the Right to Compensation"], wSieci, 20-26 October 2014.

3 Treaty on the Final Settlement with Respect to Germany, 1990. More on the German reunification treaty below. 
other similar decisions after 1990. Those deeds are stronger than any words. The case is open.

Beside the case of Poland and Germany, this article discusses the global background in the 20th and 21st centuries - in particular, the case of Greece whose reparations claims Germany rejects like the Polish claims. Also discussed are selected major cases of war reparations actually paid: by Germany for World War I, by Germany to Israel and Jewish organizations for the Holocaust of World War II, by Japan for World War II in Asia and the Pacific, and by and Iraq for the Gulf War of 1990-1991.

This is an outline of a very big and complex topic - only a preview with a preliminary and rough approximation of vitally important economic and demographic numbers. I approach the topic in an interdisciplinary way. There is no option to fully analyze, understand, and explain it in exclusively legal, exclusively economic, or exclusively political terms. By its nature, the topic belongs to the wide and multidisciplinary field of national and international security.

\section{Legal dimension: an unilateral act, never registered, never existing}

A myth persists in Poland, Germany, Europe and the world that in 1953 the then Polish People's Republic unilaterally renounced reparations from Germany for World War II, executing a political order from the Soviet Union. Supporters of the myth cite written documents and oral statements produced by the communist Polish government between 1953 and 1989.Even Poland's democratic government in the 21 st century published a collection of such documents and argued that they constituted a definite proof of the renouncement of reparations. ${ }^{4}$ However, the potentially most important document was never published. Communist and then democratic governments invoked it many times, but always without a title, date or any other specifics. Allegedly, the Polish People's Republic in 1969 - while negotiating its first bilateral treaty with West Germany - registered a1953 unilateral act of renouncement with the Secretary General of the United Nations. Also allegedly, the registered act was published in the UN collection of treaties. But in reality, it was neither published on paper, nor entered into any UN database of documents.

I directly asked the Office of Legal Affairs in the United Nations Secretariat if any Polish document of 1969 on World War II reparations exists in the UN registry of treaties and other international legal documents. Besides multilateral and bilateral treaties (agreements), the registry includes declarations and other

4 Problem reparacji, odszkodowań i świadczeń w stosunkach polsko-niemieckich 1944-2004, tom 2, Dokumenty [The Question of Reparations, Compensations, and Welfare Payments in Polish-German Relations, 1944-2004, Volume 2, Documents], redakcja S. Dębski i W.M. Góralski, Warszawa, Polski Instytut Spraw Międzynarodowych, 2004. 
unilateral acts related to treaties and other international agreements. All unilateral acts on reparations are related to treaties ending World War II and creating the present international order in Europe and beyond. The answer from New York was negative: no document existed and no registration took place. ${ }^{5}$ Therefore, no act of renouncement by Poland of reparations from Germany became legally binding in international law.

World War II reparations for many countries were based on, and regulated by, international treaties. Therefore, any renouncement of those reparations - that is, a change of the rights and obligations of the involved nations - required an act with a high legal status equivalent to the status of treaties. Multilateral, bilateral, and unilateral acts obtain this status through registration with the Secretary General of the United Nations Organization. States submit unilateral acts for $U N$ registration in order to establish, confirm, and manifest the legal force of those acts. No announcement by a national government, or publication in the media, is an unquestionable proof of the international legal status. The United Nations Charter requires the registration and publication by the United Nations of all treaties and other international agreements and, by implication, other documents affecting rights and obligations of states. Unilateral acts creating or changing rights and obligations are often considered as part of the "international agreements" category. According to the UN Charter, unregistered treaties and other international agreements cannot be invoked in United Nations institutions and are, therefore, practically deprived of legal force. ${ }^{6}$ Hence, similarly deprived are unregistered documents on matters regulated by treaties and other international agreements. Unregistered unilateral acts have no international legal status regardless of the fact whether they are or are not international agreements. After a delay of several years, the People's Republic of Poland itself recognized the necessity of UN registration and publication of the1953 unilateral declaration of renouncement. The communist government alleged that it conducted the registration procedure in 1969. Later democratic governments repeated this allegation until it was proven unfounded in 2014.

Besides the registration and publication that never occurred, the myth of renouncement includes an oral remark made by a vice minister of foreign affairs of the People's Republic of Poland during a plenary session of the United Nations General Assembly in 1953. The vice minister mentioned the renouncement amid his communist propaganda speech about the state of the world. ${ }^{7}$ However, his remark had no binding force, because the vice minister was not authorized to make legal

5 The correspondence is published in: G. Kostrzewa-Zorbas, "Biliony dolarów za II wojnę światową" [“Trillions of Dollars for World War II”], wSieci, 29 September - 5 October 2014.

6 United Nations Charter, 1945, Art. 102.

7 United Nations General Assembly, Eighth Session, Official Records, 441st Plenary Meeting, 23 September 1953, New York. 
obligations for the state. According to international law, only the head of state, head of government, and minister of foreign affairs can make obligations related to treaties without specific authorization. Even if the vice minister was a representative of Poland accredited to the UN General Assembly as to an organ of an international organization, he could only act within the extent of competences of the organ - while World War II reparations were not regulated by UN-sponsored treaties. ${ }^{8}$

No diplomatic note or other document transmitting the alleged 1953 unilateral declaration of renouncement from the People's Republic of Poland to the German Democratic Republic or the Federal Republic of Germany (unrecognized by the Polish communist government until the 1970s) exists in the archives in Berlin, Warsaw, New York, or anywhere else. Found in Polish government archives, an alleged text of the 1953 declaration was unsigned and, therefore, not binding. It was likely falsified. Its language is ambiguous, renouncing "the payment of reparations to Poland" without specifying, from whom. According to later official interpretations, from the whole Germany, but in 1953, communist Poland recognized only the German Democratic Republic. Other circumstances similarly imply that if the alleged declaration had real legal force in international law, it would pertain only to East Germany and not to the Federal Republic of Germany - neither before the German reunification of 1990 nor after it. ${ }^{9}$

Thanks to the discovery of 2014, Poland regained the long lost opportunity to pursue full claims for reparations. The Polish government can demand reparations to the state itself and to other entities within it, especially - but not only - to: regional and local self-governments, including cities, towns, and rural communities; educational and cultural institutions, including universities and museums; Christian, Jewish and other religious communities; non-governmental organizations; commercial enterprises; and all individuals harmed by Nazi Germany who were citizens of Poland from 1939 on, and their descendants or relatives. Only a small minority of survivors ever received compensations yet, always in very low amounts - symbolic instead of just.

Vienna Convention on the Law of Treaties, 1969, Art. 7 and Art. 67.

"[Principle] 7. A unilateral declaration entails obligations for the formulating State only if it is stated in clear and specific terms. In the case of doubt as to the scope of the obligations resulting from such a declaration, such obligations must be interpreted in a restrictive manner. In interpreting the content of such obligations, weight shall be given first and foremost to the text of the declaration, together with the context and the circumstances in which it was formulated," United Nations General Assembly, Official Records, Sixty-first session, Supplement No. 10 (A/61/10), Report of the International Law Commission, Fifty-eighth session (1 May - 9 June and 3 July11 August 2006), Chapter IX, Unilateral acts of states, [Section] D, Text of the Guiding Principles applicable to unilateral declarations of States capable of creating legal obligations adopted by the Commission, [Subsection] 2, Text of the Guiding Principles with commentaries thereto adopted by the Commission at its fifty-eighth session, pp. 377-378 (including "Commentary"). 
All previous attempts to regain the chance for reparations failed. An argument that communist Poland was not a sovereign state - and, therefore, had no authority to renounce reparations - proved unconvincing to the world. International law and the United Nations treat the People's Republic of Poland as a sovereign Polish state with full authority in international relations. Another line of reasoning relied on the principle that obligations made under threat of military force are void, and communist Poland was under constant military threats and, in addition, economic pressure from the Soviet Union and the Warsaw Pact. ${ }^{10}$ For a very long time, however, Poland did not invoke those facts despite that there were always widely known. A sudden invocation of the now would be perceived as incredible. Very differently, a new argument based on the recently discovered fact that Poland's alleged renouncement of reparations lacked legal force and never existed might be understood and recognized by the world, including the judges of the International Court of Justice.

\section{Human and economic dimensions}

No full calculation has ever been made of the value of the human losses inflicted by the Third German Reich during the armed invasion and occupation of Poland in 1939-1945. But a comprehensive survey of the material losses caused by the Nazi German aggression and occupation was conducted during and after World War IIby the Office of War Reparations ${ }^{11}$ of the Republic of Poland - not yet the People's Republic of Poland. Large scale data collection and analysis began in September 1944 and concluded with a published final report in January $1947 .{ }^{12}$ At that time of political transition, Poland still had a non-communist vice prime minister, Stanisław Mikołajczyk - former prime minister in the London-based Polish government in exile. Many outstanding non-communist technocrats and experts still worked for the government - for instance, Eugeniusz Kwiatkowski, famous as the main builder of the seaport and city of Gdynia before World War II. Due to the presence of politicians and professionals like those, the 1947 report is generally credible. It is not complete and perfect, however, and it could only apply the economic and other methodology existing over seventy years ago. Needing a major enhancement, it remains irreplaceable.

According to the 1947 report, the material losses inflicted on Poland by the Third German Reich amount to 258 billion Polish zlotys or 49 billion US dollars of August 1939, the last month before the outbreak of World War II in Europe. The most

10 Vienna Convention on the Law of Treaties, 1969, Art. 52, Coercion of a State by the threat or use of force, „A treaty is void if its conclusion has been procured by the threat or use of force in violation of the principles of international law embodied in the Charter of the United Nations."

11 In Polish: Biuro Odszkodowań Wojennych (BOW).

12 Biuro Odszkodowań Wojennych przy Prezydium Rady Ministrów Rzeczypospolitej Polskiej, Sprawozdanie w przedmiocie strat i szkód wojennych Polski w latach 1939-1945, Warszawa 1947. 
conservative method of calculation of the change of value of money over time is by using a price inflation index - in the case of US dollars, the Consumer Price Index of the Bureau of Labor Statistics. ${ }^{13}$ It is the only available measure of price inflation for the whole time period from 1939 to 2018 . There is no reliable world inflation data. No other currency had global importance both in 1939 and 2018, whereas the Polish currency lost continuity during World War II and under communism.

The buying power of 49 billion US dollars of August 1939 equals 895 billion US dollars or 3.276 trillion Polish zlotys in August 2018, the latest month covered by data provided by the Bureau of Labor Statistics at the time of the writing of this article. This nominal multiplication over nearly eighty years is due only to accumulated effects of price inflation, without counting in any cost of money or punitive interest rate the perpetrator of the death and destruction may be also asked to pay. For example, a very low uniform interest rate of 2 percent annually, applied for 79 years from 1939 to 2018, would produce a compound multiplier of 4.67, resulting in astronomical final amounts of 4.18 trillion US dollars or 15.299 trillion Polish zlotys. But this is just the beginning of a complete calculation.

Beside purely material losses - like demolished buildings and stolen equipment - the 1947 report covered a fraction of human losses: only those that had a simple economic equivalent. Counted in was the value of production lost due to Nazi German-inflicted deaths, disabilities and deteriorated health of Poland's labor force. Not counted in was the broader economic and social value of human lives the methods of evaluating it only began to emerge at the time of the report. Also omitted were losses in natural population growth, and the lasting psychological trauma of survivors.

Now the average value of one human life for the economy and society - in developed countries, including Poland - is most often estimated at one million US dollars. In some countries, the upper limit of estimates exceeds 10 million US dollars. Nazi Germany killed approximately 5.6 million citizens of Poland, of whom about 3 million were Polish Jews - about half of European Jews exterminated in the Holocaust. In Poland from 1939 to 1945, the economic and social value of a human life was much lower than one million US dollars of 1939, but it would likely reach that order of magnitude now, with accumulated effects of 79 years of price inflation. Hence, the total monetary value of the losses of human lives amounts to approximately 5.6 trillion US dollars of 2018, without interests rate effects, and without counting the losses in natural population growth, psychological trauma, most of the enormous damage to the physical health of survivors, and their lost education opportunities under Nazi German occupation. Based on incomplete data, the amount of 5.6 trillion US dollars of 2018, or 20.496 trillion Polish zlotys of 2018, is only a preliminary estimate.

13 United States Department of Labor, Bureau of Labor Statistics, CPI Inflation Calculator, https:// www.bls.gov/data/inflation_calculator.htm (last accessed: 3 October 2018). 
The combined value of human losses (without the value of lost natural population growth, of psychological trauma, of most health damage, and of lost education) and material losses amounts to 6.495 trillion US dollars of 2018 or 23.772 trillion Polish zlotys of 2018 (without interest). This sum is higher than nominal Net National Wealth of Poland in 2014, estimated by the World Bank at 5.889 trillion US dollars, of which as much as 4.311 trillion US dollars is the value of human capital ${ }^{14}$ (no newer estimates are available). With no World War II losses, or with a full compensation for them, Poland would be more than twice as wealthy as today. Compared to Poland's present productive capabilities, the sum 6.495 trillion US dollars equals the value of 12 years and 4 months of the nominal Gross Domestic Product of 2017 - the largest annual GDP in the history of the country. ${ }^{15}$

\section{World background, 1918-2018}

These extremely big numbers are not surprising. In 2016, the Greek government used modern methodology to calculate the value of material and cultural losses without human losses suffered by Greece in World War II. Greece is several times smaller than Poland. The Nazi German occupation of Greece was much shorter and aimed at enslavement but not total destruction of the conquered country and its citizens, except Greek Jews whose fate became part of the Holocaust. Nevertheless, the total value was 279 billion euros of 2016. Due to inflation of the euro - as measured by the Harmonised Indices of Consumer Prices of Eurostat - the value rose to 285 billion euros ${ }^{16}$ or 331 billion US dollars of 2018. Poland's estimates of material and cultural losses would be higher in absolute terms but similar in proportion to the death and destruction. Conducted independently, the Greek and Polish calculations make each other more credible.

War crimes and war reparation claims have no statute of limitations. As recently as in 2010, Germany completed the payment of reparation for World War I. The Federal Republic of Germany was paying reparations for the actions of the German Empire, despite that after its collapse, a series of five different successor German states followed - states with different territories and political systems. The last payment alone exceeded 100 million US dollars of 2018.

14 G.-M. Lange, Q. Wodon, and K. Carey, Editors, The Changing Wealth of Nations 2018: Building a Sustainable Future, World Bank Group, Washington, DC, USA, 2018, pp. 225-233. Germany's Net National Wealth in 2014 is estimated there at 59.041 trillion US dollars, while the world's, 1.14325 quadrillion US dollars.

15 Approximately 525 billion US dollars according to: International Monetary Fund, World Economic Outlook Database, https://www.imf.org/external/pubs/ft/weo/2018/01/weodata/index.aspx (last accessed: 3 October 2018).

16 [European Union,] European Commission, Eurostat, Harmonised Indices of Consumer Prices (HICP), https://ec.europa.eu/eurostat/web/hicp/data/database, last accessed: 3 October 2018). 
German reparations for World War II became dependent on and obscured by the international politics of the Cold War. It is difficult for Poland to invoke the cases of France, the Netherlands, and other West European countries, because the real sums paid to them by West Germany are impossible to determine. It is known, however, that Japan - the second most important member of the Axis - paid 966 billion US dollars of 2018 to several Asian and Pacific Ocean countries. In absolute numbers, those Japanese payments are the largest war reparations ever made in the world. They did not block Japan's postwar reconstruction, economic miracle, and advancement to near the top of the ranking of the most modern and most wealthy nations of the world.

On the basis of a treaty of 1952 between the then newly established State of Israel and West Germany, reparations in the amount of over 8 billion 2018 US dollars were provided partly to Israel - as a historical successor to European Jewish families and communities that perished in the Holocaust without survivors heirs and heirs - and partly to non-governmental organizations of Holocaust victims. In addition, the Federal Republic of Germany paid and continues to pay compensations to individuals. The grand total of all reparations and compensations paid by Germany to Israel and the Jewish diaspora before and after the German reunification amounts to 80 billion US dollars of 2018, as calculated by Jewish Telegraphic Agency. ${ }^{17}$ In the 21 st century, Germany began providing to Israel a fleet of advanced submarines that will likely become a vital components of Israeli deterrent forces - mostly for free, de facto as another form of reparations.

The newest, economically most comprehensive, and institutionally most advanced process of payments of war reparations in the world is today near successful completion in the Middle East and Persian Gulf area, involving also many countries of other world regions. Iraq is paying for the effects of the invasion and occupation of Kuwait in 1990-1991, including the harm done to third nations and other subjects. It is the only case of war reparations decided upon and managed by the United Nations Security Council. All the harmed entities, from sovereign states to commercial corporations and natural persons, are entitled to compensation. ${ }^{18}$ The UN Security Council did not wave the reparations despite that, after the Gulf War of 1990-1991, Iraq underwent historic changes, including the overthrow of Saddam Hussein and then the difficult fight of the new Iraqi government against Islamic State and other Jihadist forces. Divided into tranches and spread over many years in order to protect the Iraqi economy, the awarded payments amount to a total of

17 U. Heilman, \$ 70 Billion on, Claims Conf[erence]Marks 60 Years of Reparations from Germany, Jewish Telegraphic Agency (JTA), https://www.jta.org/2012/07/11/news-opinion/united-states/70-billion-onclaims-conf-marks-60-years-of-reparations-from-germany (last accessed: 3 October 2018).

18 United Nations Compensation Commission (UNCC), https://uncc.ch/home (last accessed: 3 October 2018). See also: War Reparations and the UN Compensation Commission: Designing Compensation After Conflict, Edited by T.J. Feighery, Ch.S. Gibson, and T.M. Rajah, New York, NY: Oxford University Press, 2015. 
74 billion US dollars of 2018. Iraq's Net National Wealth as of 2014 is estimated at 3.587 trillion US dollars, equal to only 6.08 percent of Germany's 59.041 trillion US dollars. ${ }^{19} \mathrm{~A}$ similar difference results from comparing both countries' nominal annual GDP: 198 billion US dollars and3.685 trillion US dollars in 2017, respectively. ${ }^{20}$ Iraq's economy produces only 5.37 percent of what Germany's production amounts to. If multiplied by the ratio of GDP, the sum of 74 billion 2018 US dollars of Iraqi war reparations for the Gulf War would mean 1.378 trillion 2018 US dollars for the German economy. This would greatly exceed the possible reparation claims by Poland regarding material losses - but not human losses - inflicted by the Third German Reich in World War II, as estimated above.

Because of major increases of Net National Wealth and Gross Domestic Product of most countries in modern history, the monetary value of old war reparations such as those paid shortly after the end of World War I in 1918 and the end of World War II in 1945 - does not fully represent their economic value, even with price inflation calculated in. Reparations paid many decades ago constituted a much larger share of the economies of Germany, Japan, and other paying countries than it seems today on the basis of absolute numbers alone. Payments made without long delay were more painful for perpetrator states, or their successors, while more beneficial for victim states. Now or in the future, Germany could pay delayed reparations to Poland with no real risk of a national or international economic crisis.

\section{War reparations and territorial changes}

After World War II, the victorious great powers - the United States, the United Kingdom, and the Soviet Union - transferred to Poland large pieces of the territory of the defeated and abolished Third German Reich. Known in Poland as "the Western and Northern Lands", ${ }^{21}$ they were not awarded as reparations for the Nazi German invasion and occupation of Poland. The main objective of the great powers was to create a new geopolitical and geostrategic landscape in Europe. Their territorial design for Central Europe was partly based on centuries-old historical borders and on ethnic geography. Semi-officially, the Western and Northern Lands also constituted a compensation for the eastern half of the territory of the interwar Republic of Poland - now in Ukraine, Belarus, and Lithuania - that the Soviet Union conquered at the beginning of World War II, during the time of the German-Soviet (Hitler-Stalin, Ribbentrop-Molotov) alliance.

19 G.-M. Lange, Q. Wodon, and K. Carey, Editors, The Changing Wealth of Nations 2018: Building a Sustainable Future, World Bank Group, Washington, DC, USA, 2018, pp. 225-233.

20 International Monetary Fund, World Economic Outlook Database, https://www.imf.org/external/ pubs/ft/weo/2018/01/weodata/index.aspx (last accessed: 3 October 2018).

21 Or "the Western and Northern Territories," or shortly "the Western Territories", and also "the Recovered Territories" - always with the same meaning. 
In 1990, modern German borders with all neighbors were finally and permanently determined, in their present shape, by the German reunification treaty between the Federal Republic of Germany, the German Democratic Republic, the United States, the United Kingdom, France, and the Soviet Union whose successor today is Russia- the " $2+4$ Treaty" as it is also informally known due to the composition of its parties. ${ }^{22}$ The present German-Polish border was additionally confirmed by a bilateral border treaty of 1990 . Because both treaties establish international boundaries, international law prohibits all parties to those treaties - including the reunited Germany - from denouncing them by invoking a fundamental change of circumstances (the rebus sic stantibus principle), even if the German government considers future Polish claims for World War II reparations to be such a change. ${ }^{23}$

Although the German reunification treaty of 1990 is formally called the "Treaty on the Final Settlement with Respect to Germany," it says nothing on reparations for World War II. Therefore, it does not preclude claims for reparations. Neither does the bilateral German-Polish "Treaty on Good Neighborly Relations of Friendly Cooperation" of 1991. At the same time, the German reunification treaty directly precludes any territorial claims and attempts to expand the borders in any way by Germany. Hence, forbidden are any German diplomatic actions, legal suits, or threats of any kind regarding the now Polish Western and Northern Lands. The reunification treaty says that "The confirmation of the definitive nature of the borders of the united Germany is an essential element of the peaceful order in Europe."24 By denouncing or breaking the reunification treaty, Germany would lose unity and sovereignty. The open question of reparations is independent of the closed case of borders.

\section{Practical conclusions: international litigation and diplomacy}

Poland should add an evaluation of human losses to the Office of War Reparations report of 1947 and generally verify and update the report with the application of advanced methodology of demographics, anthropology, medicine and psychology (to estimate physical and mental health damage and trauma), economics, civil engineering, and other fields of science and practical knowledge. After that, Poland may invite Germany to diplomatic negotiations intended to reach a mutually satisfactory resolution - or Poland may sue Germany for World War II reparations before the International Court of Justice in The Hague, also known under an informal name of "the World Court" because of its status of the main judicial organ of the United Nations. It settles, among other disputes, war reparations disputes between sovereign states.

Treaty on the Final Settlement with Respect to Germany, 1990, Art. 1.

3 Vienna Convention on the Law of Treaties, 1969, Art. 62.

24 Treaty on the Final Settlement with Respect to Germany, 1990, Art. 1. 
There would be obstacles due to time limits set by both Germany and Poland in their declarations recognizing the jurisdiction of the Court as compulsory, but Poland could change its declaration in advance and overcome the German declaration by invoking universal legal conventions pertaining to wars and human rights. At the end, all uncertainties regarding jurisdiction are resolved by the Court itself. The probability of a German victory in international litigation would not be high. This may convince Germany to accept instead a more realistic diplomatic compromise, like a limited payment of an agreed percentage of claims over a long period of time.

International law allows states to unilaterally annul or amend unilateral declarations - because of, among other reasons, a fundamental change of circumstances. The possibility of withdrawal was confirmed by the International Law Commission in an opinion, citing International Court of Justice verdicts, prepared for the UN General Assembly. Established exceptions do not affect the unilateral renouncement by Poland of World War II reparations. ${ }^{25}$ However, it is politically more difficult to revoke an old unilateral declaration than to announce the newly discovered fact that it never became part of the international legal order and it never even existed. A problem of war reparations still exists for Poland, Greece, and Germany. But they can find proven solutions and good practices in the world.

\section{BIBLIOGRAPHY}

[1] Biuro Odszkodowań Wojennych przy Prezydium Rady Ministrów Rzeczypospolitej Polskiej, Sprawozdanie w przedmiocie strat i szkód wojennych Polski w latach 1939-1945, Warszawa 1947 [Office of War Reparations of the Presidium of the Council of Ministers of the Republic of Poland, Report on Losses and Damage of Poland in 1939-1945, Warsaw 1947].

[2] Buxbaum, R.M., "From Paris to London: The Legal History of European Reparation Claims: 1946-1953", Berkeley Journal of International Law, Vol. 31, Issue 2.

[3] Chistodoulakis, N., Germany's War Debt to Greece: A Burden Unsettled, Basingstoke, Hampshire, UK: Palgrave MacMillan, 2014.

[4] Evans, CH., The Right to Reparation in International Law for Victims of Armed Conflict, Cambridge, UK: Cambridge University Press, 2012.

[5] Heilman, U., \$70 Billion on, Claims Conf[erence] Marks 60 Years of Reparations from Germany, Jewish Telegraphic Agency (JTA), https://www.jta.org/2012/07/11/news-opinion/united-states/70billion-on-claims-conf-marks-60-years-of-reparations-from-germany (last accessed: 3 October 2018).

[6] Kostrzewa-Zorbas, G., „Biliony dolarów za II wojnę światową” [“Trillions of Dollars for World War II"], wSieci, 29 September - 5 October 2014.

25 United Nations General Assembly, Official Records, Sixty-first session, Supplement No. 10 (A/61/10), Report of the International Law Commission, Fifty-eighth session (1 May - 9 June and 3 July - 11 August 2006), Chapter IX, Unilateral acts of states, [Section] D, Text of the Guiding Principles applicable to unilateral declarations of States capable of creating legal obligations adopted by the Commission, [Subsection] 2, Text of the Guiding Principles with commentaries thereto adopted by the Commission at its fifty-eighth session, pp. 369-381. 
[7] Kostrzewa-Zorbas, G., "Mamy prawo do odszkodowań" ["We Have the Right to Compensation"], wSieci, 20-26 October 2014.

[8] Lange, G.-M., Q. Wodon, AND K., Carey, Editors, The Changing Wealth of Nations 2018: Building a Sustainable Future, World Bank Group, Washington, DC, USA, 2018.

[9] Ludi, R., Reparations for Nazi Victims in Postwar Europe, Cambridge, UK: Cambridge University Press, 2012.

[10] May, L., After War Ends: A Philosophical Perspective, Cambridge, UK; New York, NY: Cambridge University Press, 2012.

[11] Problem reparacji, odszkodowań i świadczeń w stosunkach polsko-niemieckich 1944-2004, tom 1, Studia [The Question of Reparations, Compensations, and Welfare Payments in Polish-German Relations, 1944-2004, Volume 1, Studies], redakcja naukowa W.M. Góralski; tom 2, Dokumenty [Volume 2, Documents], redakcja S. Dębski i W.M. Góralski, Polski Instytut Spraw Międzynarodowych, Warszawa 2004.

[12] Raport o stratach wojennych Warszawy, Miasto Stołeczne Warszawa, Zespół ds. ustalenia wartości strat, jakie Warszawa poniosła w wyniku II wojny światowej, Urząd Miasta Stołecznego Warszawy, Warszawa, 2004 [Report on War Losses of Warsaw, Capital City of Warsaw, Committee for the Determination of War Losses of Warsaw in World War II, City Hall of the Capital City of Warsaw, Warsaw, 2004].

[13] Raport o stratach wojennych Warszawy, Część II. Problematyka podstaw prawnych roszczeń odszkodowawczych z tytułu strat wojennych, Miasto Stołeczne Warszawa, Zespół ds. ustalenia wartości strat, jakie Warszawa poniosła w wyniku II wojny światowej, Urząd Miasta Stołecznego Warszawy, Warszawa 2005 [Report on War Losses of Warsaw, Part II. Issues of Legal Foundations of Claims for Compensation for War Losses, Capital City of Warsaw, Committee for the Determination of War Losses of Warsaw in World War II, City Hall of the Capital City of Warsaw, Warsaw, 2005].

[14] Reparations for Victims of Genocide, War Crimes and Crimes Against Humanity: Systems in Place and Systems in the Making, Edited by C. Ferstman, M. Goetz, and A. Stephens, Leiden, Netherlands; Boston, MA.: Martinus Nijhoff Publishers, 2009.

[15] Reparations: Interdisciplinary Inquiries, Edited by J. Miller and R. Kumar, Oxford, UK: Oxford University Press, 2007.

[16] Saganek, P., „Unilateral Acts in Polish-German Relations”, Polish Yearbook of International Law, 2009.

[17] SAgAneK, P., Unilateral Acts of States in Public International Law, Leiden, Netherlands; Boston, MA: Brill Nijhoff, 2016.

[18] Scheiber, H.N., "Taking Responsibility: Moral and Historical Perspectives on the Japanese War-Reparations Issues", Berkeley Journal of International Law, Winter 2002, Vol. 20(1).

[19] Schelling, T.C., Value of Life, in: The New Palgrave: The World of Economics, Edited by J. Eatwell, M. Milgate, and P. Newman, London, UK: Palgrave Macmillan, 1991.

[20] The United Nations Compensation Commission: A Handbook, Compiled and Edited by M. Frigessi di Rattalma and T. Treves, The Hague, Netherlands; Boston, MA: Kluwer Law International, 1999.

[21] Treaty on the Final Settlement with Respect to Germany, 1990.

[22] United Nations General Assembly, Official Records, Sixty-first session, Supplement No. 10 (A/61/10), Report of the International Law Commission, Fifty-eighth session (1 May - 9 June and 3 July - 11 August 2006), Chapter IX, Unilateral acts of states.

[23] War Reparations and the UN Compensation Commission: Designing Compensation After Conflict, Edited by T.J. Feighery, Ch.S. Gibson, and T.M. Rajah, New York, NY: Oxford University Press, 2015. 


\section{NIEMIECKIE REPARACJE DLA POLSKI ZA II WOJNĘ ŚWIATOWA NA TLE GLOBALNYM}

Abstrakt: Żaden inny kraj świata nie doznał tak wielkich, a możliwych do zmierzenia i weryfikacji strat w zasobach ludzkich i materialnych jak Polska podczas II wojny światowej w latach 1939-1945. Według pierwszych szacunków wartość strat ludzkich i materialnych zadanych Polsce przez nazistowskie Niemcy sięga 6,495 bilionów dolarów amerykańskich z 2018 roku. Jednak Polska nigdy nie otrzymała reparacji wojennych od Niemiec. Artykuł jest wstępnym studium skomplikowanego tematu - studium interdyscyplinarnym, łączącym elementy analizy prawnej, ekonomicznej i politycznej, ponieważ należy do szerokiej i wielodyscyplinarnej dziedziny bezpieczeństwa narodowego i międzynarodowego. Obalony w artykule zostaje popularny międzynarodowo mit, że komunistyczna Polska jednostronnie zrzekła się niemieckich reparacji wojennych w 1953 roku. Następnie artykuł przedstawia globalne tło tematu w XX i XXI wieku - w szczególności sprawę Grecji, której roszczenia odszkodowawcze Niemcy odrzucają tak jak roszczenia polskie, oraz przypadki wielkich reparacji realnie wypłaconych przez Niemcy za I wojnę światową, także przez Niemcy dla Izraela i organizacji żydowskich za Holokaust, przez Japonię za II wojnę światową - japońskie reparacje, wynoszące 966 miliardów dolarów z 2018 roku, były największe w dziejach - i przez Irak za wojnę w Zatoce Perskiej. Artykuł kończy się przedstawieniem konieczności dalszych badań $\mathrm{z}$ użyciem zaawansowanej metodologii wielu nauk oraz zarysem możliwego procesu przed Międzynarodowym Trybunałem Sprawiedliwości w Hadze - lub dyplomatycznego rozwiązania problemu reparacji wojennych.

Słowa kluczowe: reparacje wojenne, odszkodowania wojenne, II wojna światowa, Polska, Niemcy, Trzecia Rzesza, nazistowskie Niemcy, zbrodnie wojenne, ludobójstwo, Holokaust, Żydzi, Izrael, Związek Sowiecki, Związek Radziecki, Japonia, Grecja, Irak, wojna w Zatoce Perskiej, prawo międzynarodowe, Narody Zjednoczone, ONZ, Międzynarodowy Trybunał Sprawiedliwości. 